\title{
Selection of Locators in Automated Design of Fixtures for Locating Workpieces During Machining
}

\author{
Hristo Metev \\ Department of Mechanical \\ Engineering Equipment and \\ Technologies \\ Technical University of Gabrovo \\ Gabrovo, Bulgaria \\ hmetev@abv.bg
}

\author{
Kalin Krumov \\ Department of Mechanical \\ Engineering Equipment and \\ Technologies \\ Technical University of Gabrovo \\ Gabrovo, Bulgaria \\ kalin_krasimirov_krumov@abv.bg
}

\author{
Ali Gitan \\ Department of Mechanical \\ Engineering Equipment and \\ Technologies \\ Technical University of Gabrovo \\ Gabrovo, Bulgaria \\ homam@abv.bg
}

\begin{abstract}
Using the systematic approach, the possible basing schemes of the workpieces in the machining attachments have been discovered and systematized with a view to their use in automated design. The analysis shows that the use of the proposed systematization in computeraided design is significantly more rational, since the structure reflects the sequence of choice of the optimal basing scheme analysis of the theoretical basing scheme, analysis of the geometry of the workpiece, formation of the possible list of the basing schemes. An analysis was performed with the help of which the criteria for geometric compatibility were revealed, allowing to make a choice of a basing scheme, satisfying the geometric shape of the workpiece. An algorithm for selection of locators has been developed. The development is part of a system for automated design of fixtures for locating of workpieces during machining.
\end{abstract}

Keywords - locating of workpieces; fixtures; basing schemes; locators; computer aided design.

\section{INTRODUCTION}

The development of systems for automation of engineering work has necessitated the development of systems for automated design and in particular fixtures for locating workpieces, which include newer tools, libraries, functional applications and levels of integration.

Compared to manual design, the use of CAD /CAE systems makes it possible to reduce manual labor and increase the quality of design, but does not allow complex automation, as the key stages (choosing the optimal scheme of basing (SB), calculating clamping forces, selection of construction of the locators) is done manually [1] - [5].
One of the most complex tasks in the automated design of fixtures is the selection of an optimal scheme of basing the workpieces, so the purpose of this work is to systematize the possible schemes of basing and selection of locators in order to use them in automated design.

\section{GENERAL REgUlations}

- Systematization of the schemes of basing the workpieces

The analysis of the existing systematizations of the possible schemes of basing shows that the most rational is the one proposed in [6], in which several possible realizations correspond to one theoretical SB, the number of which depends on the geometric shapes of the surfaces used for location technological bases (LTB).

Since the workpieces are based on planar $(\mathrm{P})$, external $\left(\mathrm{Cl}^{\mathrm{e}}\right)$ and internal $\left(\mathrm{Cl}^{\mathrm{i}}\right)$ cylindrical, external $\left(\mathrm{Cn}^{\mathrm{e}}\right)$ and internal $\left(\mathrm{Cn}^{\mathrm{i}}\right)$ conical surfaces, different combinations of geometric shapes of the base surfaces are obtained (PPP, $\mathrm{PPCl}^{\text {e }}$, etc.), occurring in practice, and a different number of realizations of SB from these combinations. Moreover, several possible combinations of geometric shapes of workpiece surfaces, used for LTB, correspond to a theoretical SB [6],[7].

The workpieces are based on one or several LTB, one of which is the main, providing the best orientation of the workpiece, depriving it of three (main plane LTB), four (double guide LTB) or five (support guide LTB) degrees of freedom. 
A surface ensuring a stable position of the workpiece in the fixture is chosen as the main base. The relatively largest surface area of the workpiece is chosen.

The main LTB, depending on the degrees of freedom taken away and their symbols are given in Table 1, and the most frequently used locators - in Table 2 . According to the number of deprived degrees of freedom and the geometric shape of LTB, locators are grouped as shown in Table 3.

TABLE 1 TYPES OF LOCATIONS ON TECHNOLOGICAL BASES

\begin{tabular}{|c|c|c|c|}
\hline $\begin{array}{l}\text { Geometric } \\
\text { shape of } \\
\text { the surface }\end{array}$ & $\begin{array}{c}\text { Deprived } \\
\text { degrees } \\
\text { of freedom }\end{array}$ & Name & Definition \\
\hline \multirow{3}{*}{$\begin{array}{l}\text { Plain } \\
\text { (P) }\end{array}$} & 3 & $\begin{array}{c}\text { main } \\
\text { (primary) }\end{array}$ & MP \\
\hline & 2 & guide & $\mathrm{G}$ \\
\hline & 1 & support & $\mathrm{S}$ \\
\hline \multirow{4}{*}{$\begin{array}{l}\text { Cylindrical } \\
\text { (Cl) }\end{array}$} & 4 & $\begin{array}{l}\text { double } \\
\text { guide }\end{array}$ & DG \\
\hline & 3 & main & MCl* \\
\hline & 2 & $\begin{array}{c}\text { double } \\
\text { support } \\
\text { (centering) }\end{array}$ & DS \\
\hline & 1 & support & $\mathrm{S}^{* *}$ \\
\hline \multirow{3}{*}{$\begin{array}{l}\text { Conical } \\
\text { (Cn) }\end{array}$} & 5 & $\begin{array}{l}\text { support } \\
\text { guide }\end{array}$ & SG \\
\hline & 3 & $\begin{array}{c}\text { support } \\
\text { centering }\end{array}$ & SC \\
\hline & 2 & $\begin{array}{c}\text { double } \\
\text { support } \\
\text { (centering) } \\
\end{array}$ & DS*** \\
\hline $\begin{array}{c}\text { Spherical } \\
\text { (Sp) }\end{array}$ & 3 & $\begin{array}{c}\text { triple } \\
\text { support }\end{array}$ & TS \\
\hline \multicolumn{4}{|c|}{$\begin{array}{l}\text { * When using a floating (self-locating) long V-blok [8] } \\
\text { ** When using a floating (self-locating) short V-blok } \\
\text { *** Floating center or movable rear center }\end{array}$} \\
\hline
\end{tabular}

Combining the possible LTB with the possible used locators, the possible schemes of full basing were obtained (Table 4) [8].

The choice of LTB for a particular operation depends on various factors. Thus, the use of this systematization in computer-aided design is significantly more rational, as its structure reflects the sequence of selection of optimal LTB - analysis of the theoretical LTB, analysis of the geometry of the workpiece, formation of a possible list of LTB.

If the described system is applied to a specific workpiece, it is noticed that not all SB are applicable, which is determined by the geometric incompatibility of the workpiece and locators, which implement it. An important role is played by the geometric characteristics of the workpiece: the presence of stamping or casting slopes; location of the bases of the workpiece, not allowing the implementation of the selected combination of locators, etc.

TABLE 2 LOCATORS

\begin{tabular}{|c|c|}
\hline Locators & Definition \\
\hline Support (cylindrical or flat) & $\mathrm{S}$ \\
\hline V-block long & $\mathrm{V}_{\mathrm{l}}$ \\
\hline V-block long floating & $\mathrm{V}_{\mathrm{lf}}$ \\
\hline V-block short & $\mathrm{V}_{\mathrm{s}}$ \\
\hline V-block short floating & $\mathrm{V}_{\mathrm{sf}}$ \\
\hline Pin cylindrical & $\mathrm{P}$ \\
\hline Diamond pin cylindrical & $\mathrm{P}_{\mathrm{d}}$ \\
\hline Cylindrical mandrel & $\mathrm{M}_{\mathrm{c}}$ \\
\hline Diamond mandrel cylindrical & $\mathrm{M}_{\mathrm{cd}}$ \\
\hline Taper mandrel & $\mathrm{M}_{\mathrm{t}}$ \\
\hline Bushing cylindrical long & $\mathrm{B}_{\mathrm{cl}}$ \\
\hline Bushing cylindrical short & $\mathrm{B}_{\mathrm{cs}}$ \\
\hline Taper bush long & $\mathrm{B}_{\mathrm{tl}}$ \\
\hline Taper bush short & $\mathrm{B}_{\mathrm{ts}}$ \\
\hline Centre hard & $\mathrm{C}_{\mathrm{h}}$ \\
\hline Centre rotating & $\mathrm{C}_{\mathrm{r}}$ \\
\hline Centre floating & $\mathrm{C}_{\mathrm{f}}$ \\
\hline
\end{tabular}

TABLE 3 APPLICATION OF LOCATORS

\begin{tabular}{|c|c|c|c|c|c|}
\hline $\begin{array}{c}\text { Geometric } \\
\text { shape of } \\
\text { LTB }\end{array}$ & \multicolumn{5}{|c|}{$\begin{array}{c}\text { Deprived degrees } \\
\text { of freedom }\end{array}$} \\
\cline { 2 - 6 } & 5 & 4 & 3 & 2 & 1 \\
\hline $\mathrm{P}$ & - & - & $\mathrm{S}$ & $\mathrm{S}$ & $\mathrm{S}$ \\
\hline $\mathrm{Cl}^{\mathrm{e}}$ & - & $\mathrm{V}_{\mathrm{l}}, \mathrm{B}_{\mathrm{cl}}$ & $\mathrm{V}_{\mathrm{lf}}$ & $\mathrm{S}, \mathrm{V}_{\mathrm{lf}}, \mathrm{V}_{\mathrm{s}}, \mathrm{B}_{\mathrm{cs}}$ & $\mathrm{S}, \mathrm{V}_{\mathrm{sf}}$ \\
\hline $\mathrm{Cl}^{\mathrm{i}}$ & - & $\mathrm{M}_{\mathrm{c}}$ & $\mathrm{Ch}_{\mathrm{h}}$ & $\mathrm{P}, \mathrm{M}_{\mathrm{cd}}, \mathrm{C}_{\mathrm{f}}$ & $\mathrm{P}_{\mathrm{d}}$ \\
\hline $\mathrm{Cn}^{\mathrm{e}}$ & $\mathrm{B}_{\mathrm{tl}}$ & - & $\mathrm{B}_{\mathrm{ts}}$ & - & - \\
\hline $\mathrm{Cn}^{\mathrm{i}}$ & $\mathrm{M}_{\mathrm{t}}$ & - & $\mathrm{C}_{\mathrm{h}}$ & $\mathrm{C}_{\mathrm{f}}, \mathrm{C}_{\mathrm{h}}$ & - \\
\hline $\mathrm{Sp}$ & - & - & $\mathrm{S}$ & - & - \\
\hline
\end{tabular}

When choosing the construction of locators should take into account the criteria:

- theoretical scheme of basing;

- type of locators;

- shape of the surface used for LTB;

- quality of the surface used for LTB (rough, finish, presence of casting or stamping slopes);

- maintainability;

- possibility to combine with another locator.

\section{- Algorithm for automated selection of locators}

The choice of the construction of the locators is made according to the scheme shown in Fig. 1, systematizing the construction of the locators according to the above criteria. 
Metev et al. Selection of Locators in Automated Design of Fixtures for Locating Workpieces During Machining

TABLE 4 POSSIBLE SCHEMES FOR BASING OF THE WORKPIECE

\begin{tabular}{|c|c|c|c|c|c|}
\hline Theoretical SB & Surfaces & Realizations & Theoretical SB & Surfaces & Realizations \\
\hline \multirow{27}{*}{$\mathrm{MP}+\mathrm{G}(\mathrm{DS})+\mathrm{S}$} & PPP & SSS & \multirow{29}{*}{$\begin{array}{c}\mathrm{DG}+\mathrm{S}+\mathrm{S} \\
(\mathrm{DG}+\mathrm{G})\end{array}$} & \multirow{2}{*}{$\mathrm{Cl}$ ePP } & VISS \\
\hline & \multirow{2}{*}{$\mathrm{PPCl}^{\mathrm{e}}$} & SSS & & & $\mathrm{B}_{\mathrm{cl} S \mathrm{SS}}$ \\
\hline & & $\mathrm{SSV}_{\mathrm{sf}}$ & & \multirow{5}{*}{$\mathrm{Cl}^{\mathrm{ePCl}} \mathrm{P}^{\mathrm{e}}$} & $\mathrm{V}_{\mathrm{l} S S}$ \\
\hline & $\mathrm{PPCl}^{\mathrm{i}}$ & $\mathrm{SSP}_{\mathrm{d}}$ & & & $\mathrm{B}_{\mathrm{cl}} \mathrm{SS}$ \\
\hline & \multirow{4}{*}{$\mathrm{PCl}^{\mathrm{e}} \mathrm{P}$} & SSS & & & $\mathrm{V}_{\mathrm{l} S V_{\text {sf }}}$ \\
\hline & & $\mathrm{SV}_{\text {lf }} \mathrm{S}$ & & & \multirow{2}{*}{$\mathrm{B}_{\mathrm{cl}} S V_{\mathrm{sf}}$} \\
\hline & & $\mathrm{SV}_{\mathrm{s}} \mathrm{S}$ & & & \\
\hline & & $\mathrm{SB}_{\mathrm{CS}} \mathrm{S}$ & & \multirow{2}{*}{$\mathrm{Cl}^{e} \mathrm{PCl}^{\mathrm{i}}$} & $\mathrm{V}_{\mathrm{lSP}}$ \\
\hline & \multirow{6}{*}{$\mathrm{PCl}^{\mathrm{e}} \mathrm{Cl}^{\mathrm{e}}$} & SSS & & & $\mathrm{B}_{\mathrm{cl}} \mathrm{SP}_{\mathrm{d}}$ \\
\hline & & $\mathrm{SV}_{\mathrm{s}} \mathrm{S}$ & & \multirow{3}{*}{$\mathrm{Cl}^{\mathrm{e}} \mathrm{Cl}^{\mathrm{e}}$} & $\mathrm{VIV}_{\mathrm{s}}$ \\
\hline & & $\mathrm{SB}_{\mathrm{CS}} \mathrm{S}$ & & & $\mathrm{B}_{\mathrm{cl}} \mathrm{V}_{\mathrm{s}}$ \\
\hline & & $\mathrm{SSV}_{\mathrm{sf}}$ & & & $\mathrm{V}_{\mathrm{lS}}$ \\
\hline & & $\mathrm{SV}_{\mathrm{s}} \mathrm{V}_{\mathrm{sf}}$ & & \multirow{5}{*}{$\mathrm{Cl}^{\mathrm{e}} \mathrm{Cl}^{\mathrm{e}} \mathrm{Cl}^{\mathrm{i}}$} & $\mathrm{VlSP}_{\mathrm{d}}$ \\
\hline & & $\mathrm{SB}_{\mathrm{cs}} \mathrm{V}_{\mathrm{sf}}$ & & & $\mathrm{B}_{\mathrm{cl}} \mathrm{V}_{\mathrm{sf}} \mathrm{P}_{\mathrm{d}}$ \\
\hline & \multirow{4}{*}{$\mathrm{PCl}^{e} \mathrm{Cl}^{\mathrm{i}}$} & $\mathrm{SS} \mathrm{P}_{\mathrm{d}}$ & & & $\mathrm{V}_{\mathrm{l}} \mathrm{V}_{\mathrm{sf}} \mathrm{P}_{\mathrm{d}}$ \\
\hline & & $\mathrm{SV}_{\mathrm{lfP}} \mathrm{P}_{\mathrm{d}}$ & & & \\
\hline & & $\mathrm{SV}_{\mathrm{s}} \mathrm{P}_{\mathrm{d}}$ & & & $\mathrm{B}_{\mathrm{cl}} S P_{\mathrm{d}}$ \\
\hline & & $\mathrm{SB}_{\mathrm{cs}} \mathrm{P}_{\mathrm{d}}$ & & \multirow{2}{*}{$\mathrm{Cl}^{\mathrm{e}} \mathrm{Cl}^{\mathrm{i}}$} & $\mathrm{V}_{\mathrm{l}} \mathrm{P}$ \\
\hline & \multirow{2}{*}{ PCliP } & $\mathrm{SP}_{\mathrm{d}} \mathrm{S}$ & & & $\mathrm{B}_{\mathrm{cl}} \mathrm{P}$ \\
\hline & & $\mathrm{S} \mathrm{M}_{\mathrm{cd}} \mathrm{S}$ & & \multirow{2}{*}{$\mathrm{Cl}^{\mathrm{e}} \mathrm{Cl}^{\mathrm{i}} \mathrm{Cl}^{\mathrm{i}}$} & $\mathrm{V}_{\mathrm{l}} \mathrm{P}_{\mathrm{d}} \mathrm{P}_{\mathrm{d}}$ \\
\hline & \multirow{4}{*}{$\mathrm{PCl}^{\mathrm{i} C l}{ }^{\mathrm{e}}$} & SPS & & & $\mathrm{B}_{\mathrm{cl}} \mathrm{P}_{\mathrm{d}} \mathrm{P}_{\mathrm{d}}$ \\
\hline & & $\mathrm{SM}_{\mathrm{cd}} \mathrm{S}$ & & $\mathrm{Cl}^{\mathrm{i} P P}$ & $\mathrm{M}_{\mathrm{c}} \mathrm{SS}$ \\
\hline & & $\mathrm{SM}_{\mathrm{cd}} \mathrm{V}_{\mathrm{sf}}$ & & \multirow{2}{*}{$\mathrm{Cl}^{\mathrm{i}} \mathrm{PCl}{ }^{\mathrm{e}}$} & $\mathrm{M}_{\mathrm{c}} \mathrm{SS}$ \\
\hline & & $\mathrm{SP} \mathrm{V}_{\mathrm{sf}}$ & & & $\mathrm{M}_{\mathrm{c}} \mathrm{S} \mathrm{V}_{\mathrm{sf}}$ \\
\hline & \multirow{3}{*}{$\mathrm{PCl}^{\mathrm{i} C l}{ }^{\mathrm{i}}$} & $\mathrm{SPP}_{\mathrm{d}}$ & & $\mathrm{Cl}^{\mathrm{i}} \mathrm{PCl}^{\mathrm{i}}$ & $\mathrm{M}_{\mathrm{c}} \mathrm{SP}_{\mathrm{d}}$ \\
\hline & & $\mathrm{SM}_{\mathrm{cd}} \mathrm{P}_{\mathrm{d}}$ & & \multirow{2}{*}{$\mathrm{Cl}^{\mathrm{i}} \mathrm{Cl}^{\mathrm{e}} \mathrm{Cl}^{\mathrm{i}}$} & $\mathrm{M}_{\mathrm{c}} \mathrm{SP}_{\mathrm{d}}$ \\
\hline & & $\mathrm{SC}_{\mathrm{f}} \mathrm{P}_{\mathrm{d}}$ & & & $\mathrm{M}_{\mathrm{c}} \mathrm{V}_{\mathrm{sf}} \mathrm{P}_{\mathrm{d}}$ \\
\hline \multirow{6}{*}{$S G+S$} & $\mathrm{Cn}^{\mathrm{e}} \mathrm{P}$ & $\mathrm{B}_{\mathrm{tl}} \mathrm{S}$ & & \multirow{2}{*}{$\mathrm{Cl}^{\mathrm{i}} \mathrm{Cl}^{\mathrm{i}}$} & $\mathrm{M}_{\mathrm{c}} \mathrm{P}$ \\
\hline & $\mathrm{Cn}^{\mathrm{e}} \mathrm{Cl}^{\mathrm{e}}$ & $\mathrm{B}_{\mathrm{tl}} \mathrm{V}_{\mathrm{sf}}$ & & & $\mathrm{M}_{\mathrm{c}} \mathrm{M}_{\mathrm{cd}}$ \\
\hline & $\mathrm{Cn}^{\mathrm{e}} \mathrm{Cl}^{\mathrm{i}}$ & $\mathrm{B}_{\mathrm{tl}} \mathrm{P}_{\mathrm{d}}$ & \multirow{2}{*}{$\mathrm{SC}+\mathrm{DS}+\mathrm{S}$} & \multirow{2}{*}{$\mathrm{Cn}^{\mathrm{i}} \mathrm{Cn}^{\mathrm{i}} \mathrm{P}$} & $\mathrm{C}_{h} \mathrm{C}_{h} \mathrm{~S}$ \\
\hline & $\mathrm{Cn}$ iP & $\mathrm{M}_{\mathrm{t}} \mathrm{S}$ & & & $\mathrm{C}_{\mathrm{f}} \mathrm{C}_{\mathrm{f}} \mathrm{S}$ \\
\hline & $\mathrm{Cn}^{\mathrm{i}} \mathrm{Cl}^{\mathrm{e}}$ & $\mathrm{M}_{\mathrm{t}} \mathrm{V}_{\mathrm{sf}}$ & & & \\
\hline & $\mathrm{Cn}^{\mathrm{i}} \mathrm{Cl}^{\mathrm{i}}$ & $\mathrm{M}_{\mathrm{t}} \mathrm{P}_{\mathrm{d}}$ & & & \\
\hline
\end{tabular}

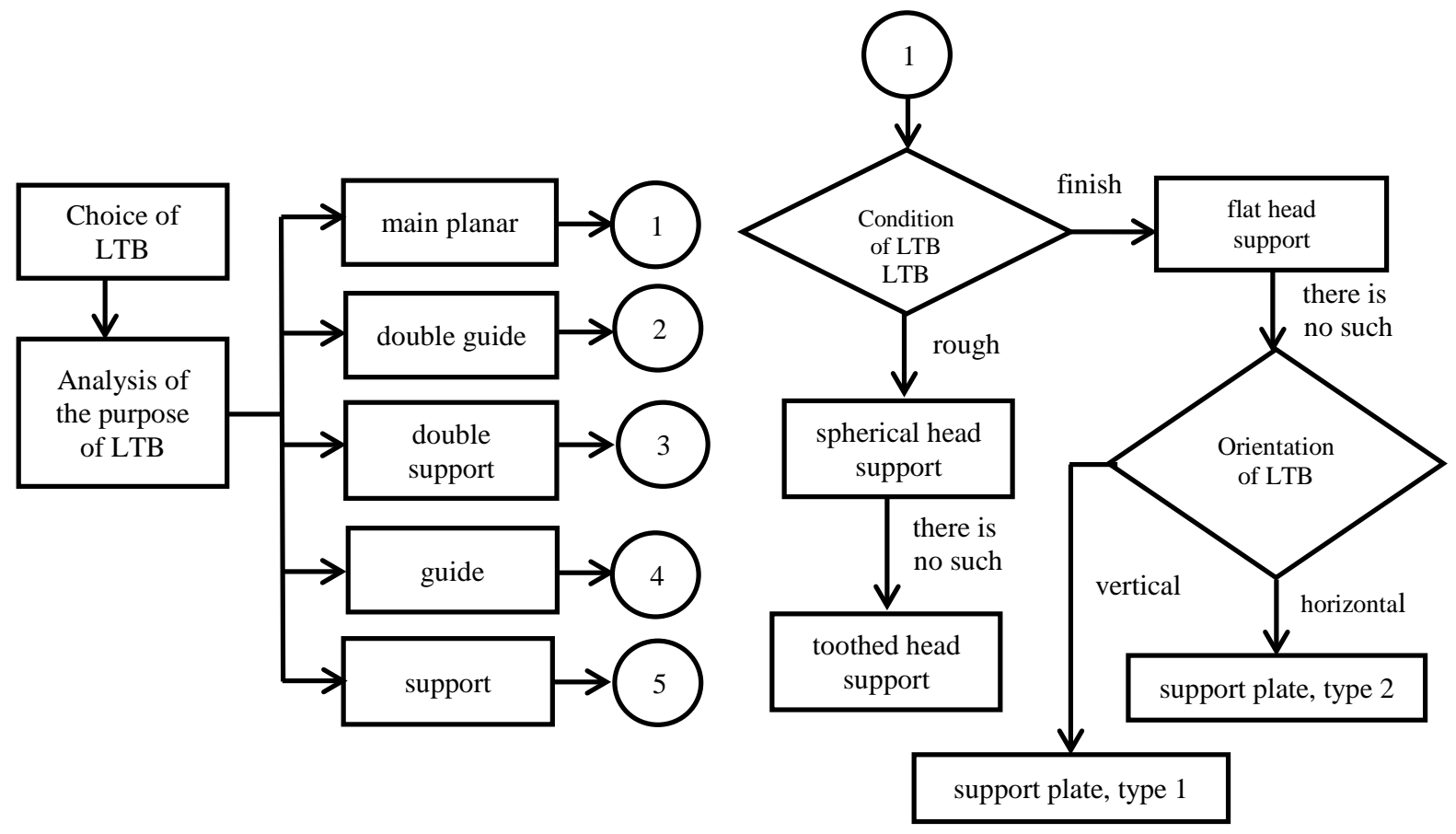

Fig. 1. Selection of locators 


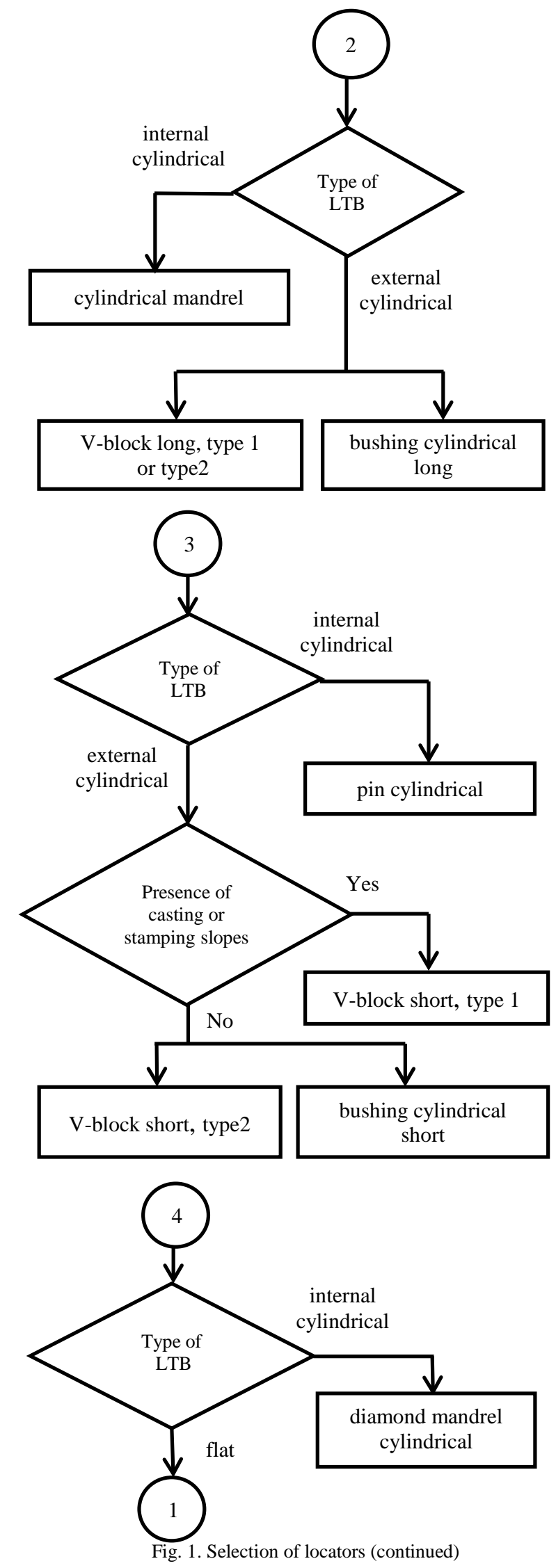

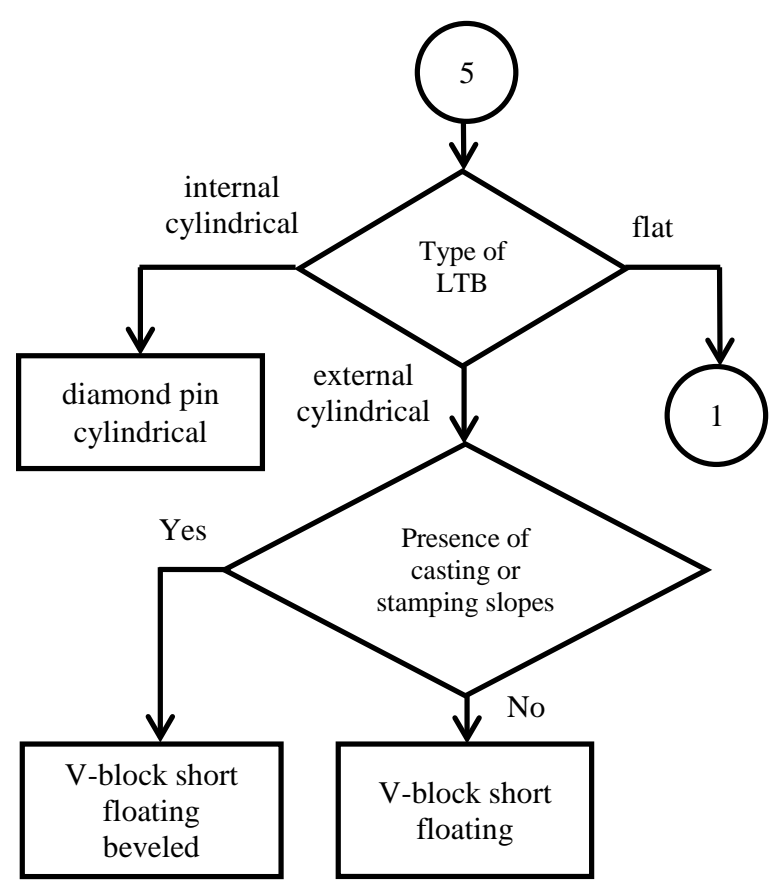

Fig. 1. Selection of locators (continued)

A database with models of locators of the fixtures in the Solid Works software environment and tables for their automated selection in the MS Excel software environment has been built, some of which are shown in Fig. 2. 


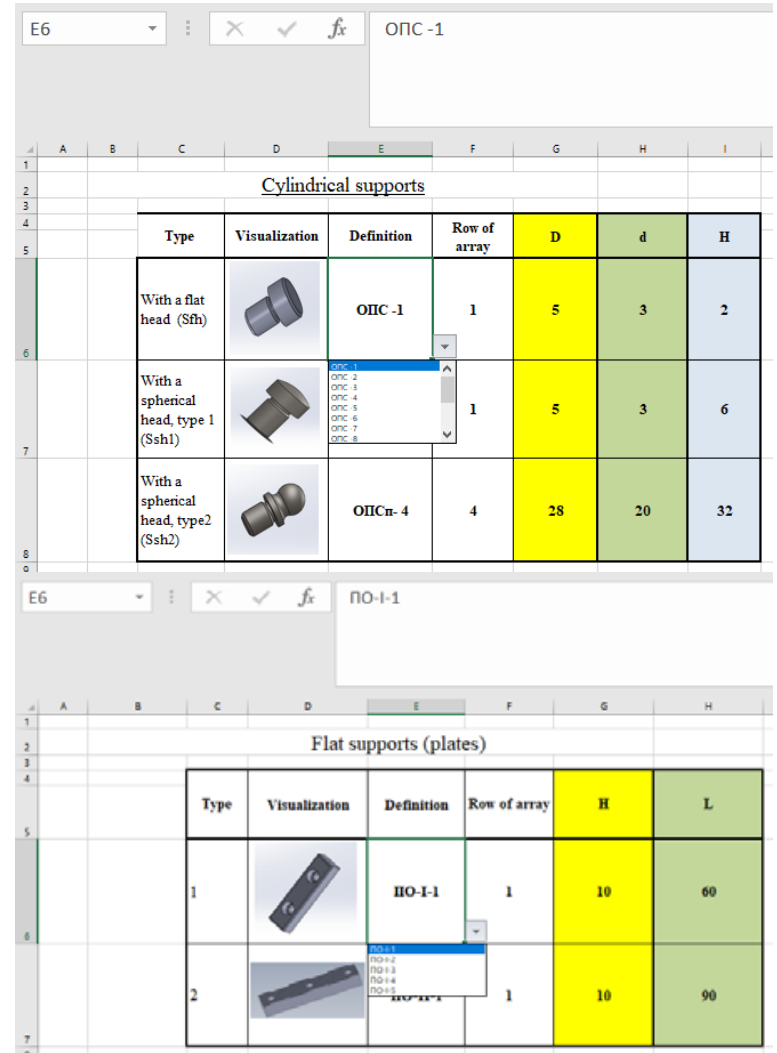

Fig. 2. Tables for automated selection of locators

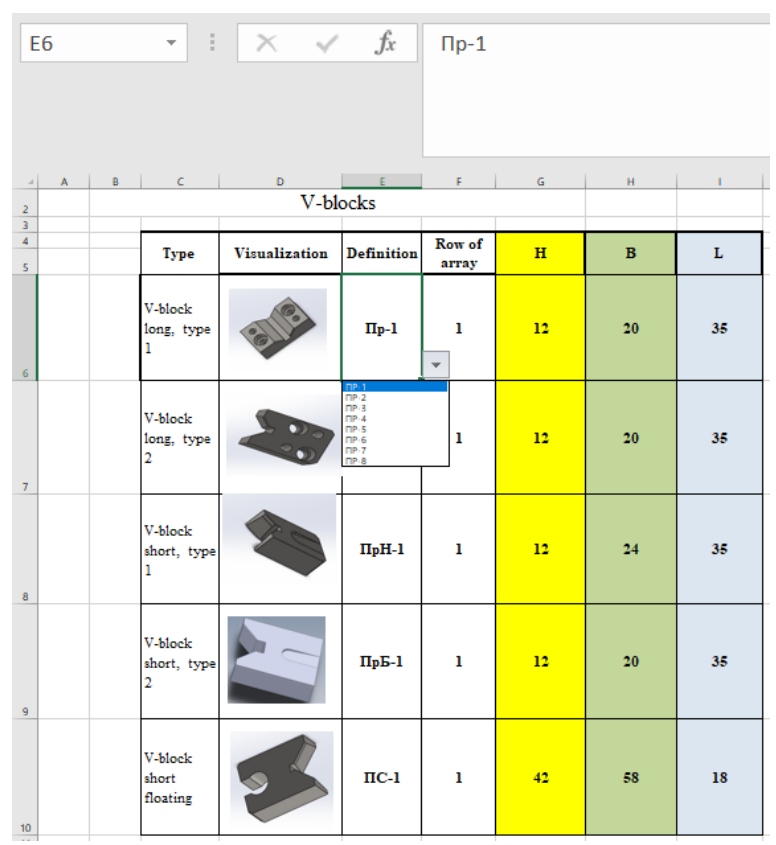

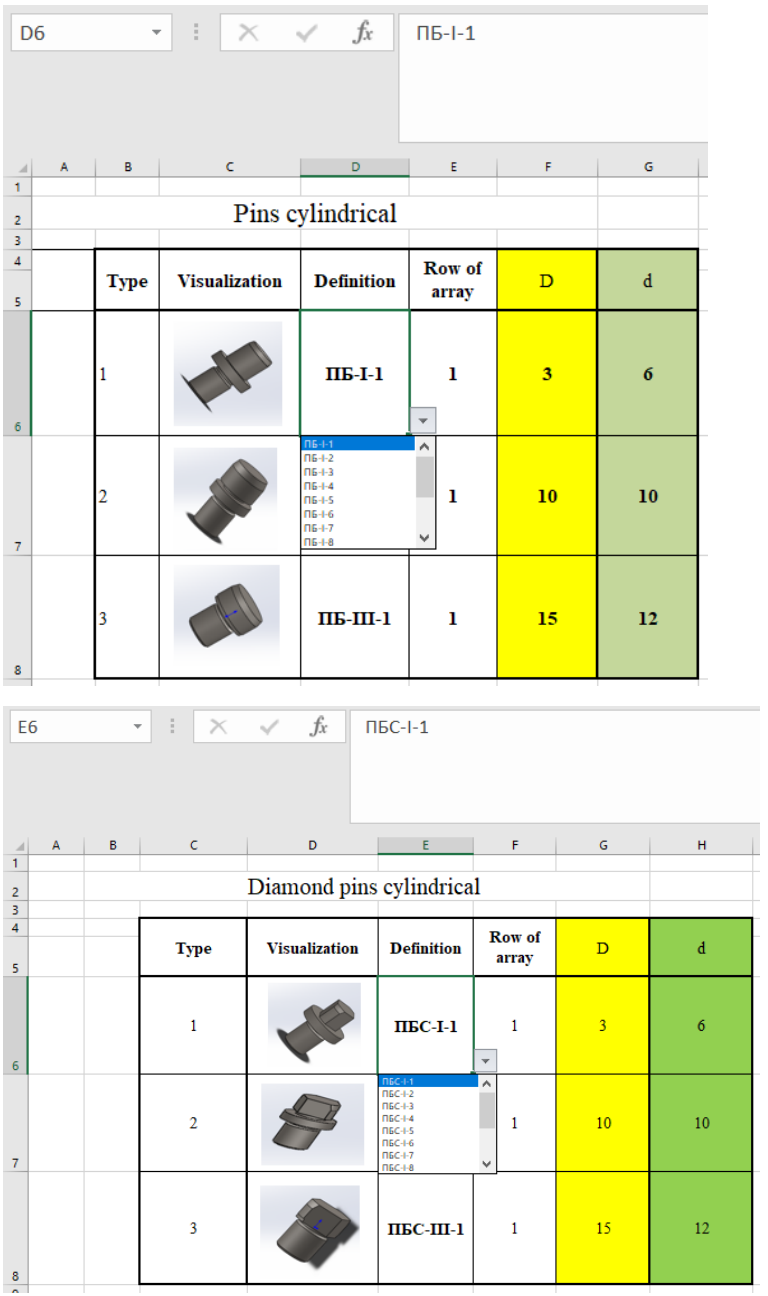

Fig. 2. Tables for automated selection of locators (continued)

\section{CONCLUSION}

1. Systematization of the possible schemes of basing the workpieces in the fixtures for locating during machining with a view to use and in automated design has been performed.

2. An algorithm for selection of locators has been developed.

3. A database with locators has been created and tables for their automated selection have been developed. The database allows the inclusion of new construction elements.

4. The obtained results are a stage of the development of a system for automated design of fixtures for locating of workpieces during machining.

\section{REFERENCES}

[1] Z.M. Bi, W.J. Zhang, Flexible fixture design and automa-tion: review, issues and future direction. International Journal of Production Research, vol.39 (13), p. 2867-2894, 2001.

[2] Raev M., Metev H., Mitev J. Analysis methods of design of arrangements for the estabilishment of the preparations for machining. International scientific conference UNITECH'15, Gabrovo, Bulgaria 2015г., vol.3, p. 101-106, 2015. 
Environment. Technology. Resources. Rezekne, Latvia Proceedings of the $13^{\text {th }}$ International Scientific and Practical Conference. Volume 3, 202-207

[3] Metev H., Raev M., Mitev J. Methodology and algorithm for computer-aided design of fixtures for the locating of workpieces in the mechanical treatment. Journal of the Technical University of Gabrovo, vol.48, p. 35-39, 2014.

[4] Vukelic D., Hodolic J. Computer aided fixtures design. University of Novi Sad. Faculty of Technical Sciences. 47-th anniversary of the faculty. 2007: 21-26.

[5] G. Nikolcheva, O. Mihaylov, Automation of the selection of the points in location by the 3-2-1 principle using a SolidWorks intigradet locating module, Scientific Proceedings of the Scientific-Technical Union Of Mechanical Engineering, vol.3, XIII
International Congress "Machines, Technologies, Materials 2016”, Varna, Bulgaria, p. 72-75, 2016.

[6] Ilickij V., B. Zotina. Design of technological equipment. Bryansk. c.123. BGTU, 2006.

[7] Metev H., Gitan A., Selection of optimal basic schemes in automatic design of fixtures for the locating of workpieces during machining. International scientific conference UNITECH'19, Gabrovo, Bulgaria, vol.2, p. 206-211, 2019.

[8] Kuzmanov T., Metev H., Tsvyatkova I. Basing workpieces analysis in mechanical working. International scientific conference UNITECH’03, Gabrovo, Bulgaria, vol.1, p. 541-543, 2003. 